\title{
Genus-specific quantitative PCR of thraustochytrid protists
}

\author{
Ryosuke Nakai ${ }^{1,2,4}$, Keiko Nakamura ${ }^{1}$, Waqar Azeem Jadoon ${ }^{1}$, Katsuhiko Kashihara ${ }^{3}$, \\ Takeshi Naganuma ${ }^{1, *}$ \\ ${ }^{1}$ Graduate School of Biosphere Science, and ${ }^{3}$ Faculty of Applied Biological Science, Hiroshima University, 1-4-4 Kagamiyama, \\ Higashi-hiroshima, Hiroshima 739-8528, Japan \\ ${ }^{2}$ Research Fellow of the Japan Society for the Promotion of Science, Chiyoda-ku, Tokyo, 102-8471, Japan \\ ${ }^{4}$ Present address: National Institute of Genetics, 1111 Yata, Mishima, Shizuoka, 411-8540, Japan
}

\begin{abstract}
Thraustochytrids have the capability to recycle refractory organic matter, with a resulting impact on carbon cycling in coastal and open seawaters. The abundance of thraustochytrids has traditionally been estimated by acriflavine direct counting. However, this technique may lead to over- or underestimation. To accurately quantify the abundance of thraustochytrids, we developed a quantitative PCR (qPCR) system using 7 genus-specific primer sets targeting 7 genera (Aurantiochytrium, Botryochytrium, Oblongichytrium, Parietichytrium, Schizochytrium, Sicyoidochytrium, and Ulkenia) from the family Thraustochytriaceae. The high specificity was verified in silico and with culture strains of each genus. In addition, we applied this qPCR assay to test for the presence of thraustochytrids in coastal and open seawaters around Japan. We successfully detected the presence of Aurantiochytrium (in the range of $1.12 \times 10^{4}$ to 1.31 $\times 10^{4}$ cells l$^{-1}$ ) and Oblongichytrium (in the range of

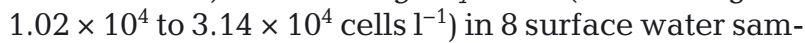
ples from around Satsuma-Iwojima (western Japan) and off the Karakuwa in Sanriku (eastern Japan). We obtained higher estimates using qPCR than the traditional acriflavine method in all cases, with a weak positive correlation between the 2 methods $\left(r^{2}=\right.$ 0.495). Interestingly, we quantified thraustochytrids in 104 additional samples by direct count, but not by qPCR, possibly because of inhibition of the qPCR reaction and/or the presence of novel thraustochytrid groups. Although these trials are preliminary, our approach can provide the genus-specific value of abundance in the environment. It will also promote further advances in our understanding of thraustochytrid diversity.
\end{abstract}

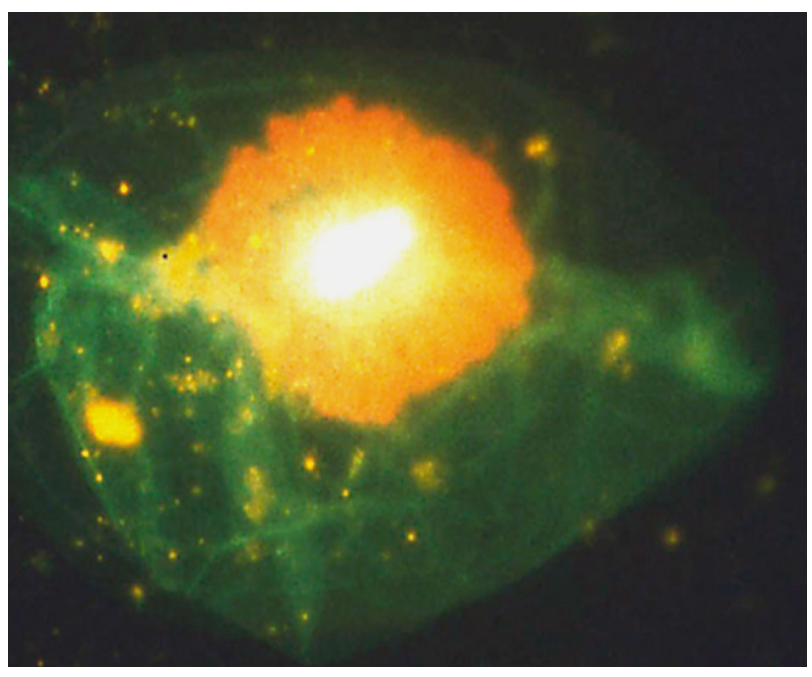

Thraustochytrid protists (here: single cell stained with acriflavine) are an often overlooked part of the marine microbial food chain.

Photo: Takeshi Naganuma

KEY WORDS: Thraustochytriaceae $\cdot$ Stramenopile $\mathrm{qPCR} \cdot 18 \mathrm{~S}$ rRNA gene $\cdot$ Abundance

Resale or republication not permitted without written consent of the publisher

\section{INTRODUCTION}

Thraustochytrids are estuarine/marine protists belonging to the family Thraustochytriaceae, of the class Labyrinthulomycetes within the kingdom Chromista (Cavalier-Smith et al. 1994, Honda et al. 1999, Cava- 
lier-Smith \& Chao 2006). They have attracted attention by virtue of their biotechnological role in the production of omega-3 long-chain polyunsaturated fatty acids (PUFAs) such as docosapentaenoic acid (DPA) and docosahexaenoic acid (DHA) (Raghukumar 2008). They have the ability to decompose plant material, such as algal tissue and mangrove leaf litter, by means of extracellular cellulase (Sathe-Pathak et al. 1993, Bremer 1995, Nagano et al. 2011), with a resulting impact on carbon cycling in coastal and open seawaters, and may grow on terrestrial refractory organic substrates contained in river water (Kimura \& Naganuma 2001). In addition, the bio-volume of thraustochytrids is $\sim 10^{3}$ times greater than that of bacterioplankton (Naganuma et al. 1998). Thus, they serve as potentially important food sources for picoplankton-feeders, thereby enhancing pelagic secondary production (Naganuma et al. 1998, Raghukumar \& Damare 2011).

The abundance of thraustochytrids has been measured in many previous studies focusing on the direct enumeration of non-planktonic or planktonic thraustochytrids (Raghukumar \& Schaumann 1993, Naganuma et al. 1998, Raghukumar et al. 2001, Naganuma et al. 2006), estimation of their biomass based on cellular carbon and nitrogen content and the $\mathrm{C}: \mathrm{N}$ ratio (Kimura et al. 1999), estimation of the correlation between their abundance and environmental parameters (Kimura et al. 2001), and determination of the effect of river discharge on their distribution and abundance (Kimura \& Naganuma 2001). These studies used a fluorogenic acriflavine dye to enumerate the thraustochytrids by direct detection. This technique relies on the fact that the wall and nucleus of thraustochytrid cells fluoresce differently (red and blue-green, respectively) under blue-light excitation. This dual fluorescence distinguishes thraustochytrids from other protists and detritus. However, the acriflavine count includes protozoan cysts, thereby leading to overestimation, and excludes thraustochytrid zoospores, leading to underestimation. In addition, there may be variation in results due to observer error. Kimura et al. (2001) pointed out that such over- or underestimation should be evaluated in future studies by using a more specific technique. To address this issue, Takao et al. (2007) developed a fluorescence in situ hybridization (FISH) method using an 18S rRNA-targeted fluorescent oligo-nucleotide probe for specific detection of thraustochytrids. Damare \& Raghukumar (2010) used an internal transcribed spacer (ITS)-based in situ hybridization (ISH) technique to detect aplanochytrids (Labyrinthulomycetes). Although FISH and ISH are powerful tools, they require many hybridization steps and intensive microscopic work.
To address these limitations and provide a simple method that can be used to process multiple samples, we developed a quantitative polymerase chain reaction (qPCR) assay. Quantification by qPCR relies on detection of the increase in fluorescence from exponentially amplified DNA by a PCR involving a primer set and/or a fluorochrome-labeled probe designed to bind to the desired DNA locus. qPCR-based quantification provides a highly sensitive and specific system for the identification of target organisms. This method is increasingly being used in marine microbiological studies, such as in the detection of dinoflagellates (Bowers et al. 2000, Moorthi et al. 2006, Yamashita et al. 2011) and the thraustochytrid pathogen quahog parasite unknown (QPX) (Lyons et al. 2006, Liu et al. 2009). In a recent report, Bergmann et al. (2011) developed a qPCR assay for detection of the labyrinthulid Labyrinthula zosterae (Labyrinthulomycetes), known as the causative agent of eelgrass wasting disease. However, except for labyrinthulomycete pathogens, there are no published reports detailing qPCR detection of thraustochytrids. We developed and evaluated a new qPCR system with genus-specific primer sets targeting thraustochytrids and then used this assay to test for the presence of thraustochytrids in field samples.

\section{MATERIALS AND METHODS}

\section{Design of genus-specific PCR primers}

We used the intercalation chemistry that employs the SYBR ${ }^{\circledR}$ Green I fluorochrome and designed the PCR primer sets based on specific regions of the 18S rRNA gene to differentiate 7 genera (Aurantiochytrium, Botryochytrium, Oblongichytrium, Parietichytrium, Schizochytrium, Sicyoidochytrium, and Ulkenia) belonging to the Thraustochytriaceae. We used 27 sequences obtained from the DDBJ/EMBL/ GenBank databases as references (Table 1). Specific regions could not be determined in 3 additional genera (Althornia, Japonochytrium, and Thraustochytrium) for a variety of reasons, including the genus being phylogenetically diverse or the unavailability of a culture strain. Ten taxa of another Chromista group were also referenced as negative targets (Table 1). The obtained sequences were aligned using Clustal X 2.0 (Larkin et al. 2007) and manually edited by eye. The primer sequences were designed from regions specific to each target genus that allowed the elimination of non-target genera, and the threshold was set at 3 nucleotide mismatches. 
Table 1. DDBJ/EMBL/GenBank accession numbers of 18S rRNA gene sequences used to design the genus-specific PCR primer sets. Asterisks ( ${ }^{*}$ ) indicate scientific names according to Yokoyama \& Honda (2007) and Yokoyama et al. (2007)

\begin{tabular}{|c|c|c|}
\hline Taxon & $\begin{array}{l}\text { Accession } \\
\text { number }\end{array}$ & $\begin{array}{c}\text { Sequence } \\
\text { length (bp) }\end{array}$ \\
\hline \multicolumn{3}{|l|}{ Genus Aurantiochytrium } \\
\hline Aurantiochytrium limacinum NIBH SR21* & AB022107 & 1678 \\
\hline Aurantiochytrium mangrovei & DQ100293 & 1721 \\
\hline Aurantiochytrium sp. KH105* & AB052555 & 1755 \\
\hline Aurantiochytrium sp. mh0186 & AB362211 & 1790 \\
\hline Aurantiochytrium sp. SEK 209 & AB290574 & 1720 \\
\hline Aurantiochytrium sp. SEK 218 & AB290573 & 1711 \\
\hline Aurantiochytrium sp. SEK 217 & AB290572 & 1764 \\
\hline \multicolumn{3}{|l|}{ Genus Botryochytrium } \\
\hline Botryochytrium radiatum SEK 353 & AB355410 & 1699 \\
\hline \multicolumn{3}{|l|}{ Genus Oblongichytrium } \\
\hline Oblongichytrium sp. SEK 347 & AB290575 & 1774 \\
\hline Oblongichytrium sp. TN6 & FJ821480 & 1798 \\
\hline Oblongichytrium sp. 8-7* & AF257317 & 1639 \\
\hline Oblongichytrium sp. $7-5^{*}$ & AF257316 & 1635 \\
\hline \multicolumn{3}{|l|}{ Genus Parietichytrium } \\
\hline Parietichytrium sarkarianum SEK 351 & AB355411 & 1756 \\
\hline \multicolumn{3}{|l|}{ Genus Sicyoidochytrium } \\
\hline Sicyoidochytrium minutum NBRC $102975^{*}$ & AB290585 & 1733 \\
\hline Sicyoidochytrium sp. NBRC $102979^{*}$ & AB183659 & 1711 \\
\hline Sicyoidochytrium minutum SEK 354 & AB355412 & 1733 \\
\hline \multicolumn{3}{|l|}{ Genus Schizochytrium } \\
\hline Schizochytrium sp. SEK 346 & AB290578 & 1766 \\
\hline Schizochytrium sp. SEK 345 & AB290577 & 1755 \\
\hline Schizochytrium sp. SEK 210 & AB290576 & 1766 \\
\hline Schizochytrium aggregatum ATCC 28209 & AB022106 & 1677 \\
\hline Schizochytrium sp. KK17-3* & AB052556 & 1793 \\
\hline \multicolumn{3}{|l|}{ Genus Ulkenia } \\
\hline Ulkenia amoeboidea SEK $214^{*}$ & AB290355 & 1790 \\
\hline Ulkenia profunda & L34054 & 1815 \\
\hline Ulkenia profunda BUTRBG 111 & DQ023615 & 1762 \\
\hline Ulkenia sp. ATCC $28207^{*}$ & AB022104 & 1760 \\
\hline Ulkenia visurgensis BURAAA 141 & DQ100296 & 1812 \\
\hline Ulkenia visurgensis ATCC 28208 & AB022116 & 1812 \\
\hline \multicolumn{3}{|l|}{ Other Chromista group } \\
\hline Cafeteria roenbergensis & L27633 & 1718 \\
\hline Achlya bisexualis & M32705 & 1809 \\
\hline Phytophthora megasperma & X54265 & 1827 \\
\hline Hyphochytrium catenoides BR217 & AF163294 & 1814 \\
\hline Chaetoceros debilis ch.4 & AY229896 & 1739 \\
\hline Eucampia antarcia CCMP1452 & AY485503 & 1632 \\
\hline Skeletonema costatum CCAP 1077/3 & X85395 & 1798 \\
\hline Thalassiosira weissflogii CCAP1085/1 & FJ600728 & 1764 \\
\hline Chattonera ovata C. Tomas Japan & AY788924 & 1781 \\
\hline Heterosigma akashiwo 893 & AB217869 & 1806 \\
\hline
\end{tabular}

\section{Testing for primer specificity to culture strains using PCR and qPCR}

To confirm that the designed primers matched 18S rRNA genes from the target genus rather than from non-target genera, we conducted a Primer-BLAST search (Altschul et al. 1997, Ye et al. 2012) against the NCBI non-redundant (nr) database with an input setting of 50 to $250 \mathrm{bp}$ for the PCR product size. In addition, the search was also performed with an input setting of 50 to $5000 \mathrm{bp}$ to examine the risks of unpredictable matching with other estuarine and marine organisms.

In addition to these database searches, we performed experimental confirmation by PCR using the above-mentioned primers against cultured strains of each genus: Aurantiochytrium sp. SEK 209 (NBRC102614), Botryochytrium radiatum SEK 353 (NBRC104107), Oblongichytrium sp. SEK 347 (NBRC102618), Parietichytrium sarkarianum SEK 351 (NBRC104108), Sicyoidochytrium sp. MBIC11077 (NBRC102979), Schizochytrium sp. SEK 345 (NBRC102616), and Ulkenia amoeboidea SEK 214 (NBRC104106). Samples of the culture (2-3 $\mathrm{ml})$ were harvested during the exponential growth stage by centrifugation (6000 $\mathrm{g} \times, 5 \mathrm{~min})$. The resultant cell pellets were suspended in $200 \mu \mathrm{l}$ of phosphatebuffered saline (PBS, $\mathrm{pH} 7.2$ ), then digested with $26 \mu \mathrm{l}$ of $10 \%$ sodium dodecyl sulfate (SDS), $20 \mu \mathrm{l}$ of $5 \mathrm{mg} \mathrm{ml}^{-1}$ lysozyme, and $40 \mu \mathrm{l}$ of $25 \mathrm{mg} \mathrm{ml}^{-1}$ Proteinase K. DNAs in the solutions were extracted with phenolchloroform-isoamyl alcohol (PCI; 25:24:1, $\mathrm{v} / \mathrm{v} / \mathrm{v}$ ) and chloroform-isoamyl alcohol (CIA; $24: 1, \mathrm{v} / \mathrm{v})$, then precipitated by isopropanol in $0.3 \mathrm{M}$ sodium acetate. The DNA pellets were washed in $70 \%$ ethanol and then finally dissolved with $100 \mu \mathrm{l}$ of sterile MilliQ water. A mixture (total volume: $20 \mu \mathrm{l})$ containing $0.5 \mu \mathrm{l}$ of template DNA (dissolved as above), $1 \mu \mathrm{l}$ of $10 \mathrm{pmol}^{\mathrm{l}} \mathrm{l}^{-1}$ genus-specific forward and reverse primers, and the recommended volume of 5 units $\mathrm{\mu l}^{-1}$ Ex Taq DNA polymerase, 10× Ex Taq buffer, $25 \mathrm{mM} \mathrm{MgCl}_{2}$, and deoxynucleoside triphosphate (dNTP) mixture included in the Takara Ex Taq kit (Takara Bio) was subjected to conventional PCR to verify the 
genus-specific amplicon from a designated thraustochytrid genus. The thermal-cycling protocol was: 1 cycle at $95^{\circ} \mathrm{C}$ for $5 \mathrm{~min}, 35$ cycles at $95^{\circ} \mathrm{C}$ for $45 \mathrm{~s}$, $60^{\circ} \mathrm{C}$ for $45 \mathrm{~s}$, and $72^{\circ} \mathrm{C}$ for $30 \mathrm{~s}$, followed by 1 cycle at $72^{\circ} \mathrm{C}$ for 5 min. PCR was conducted in a Takara PCR Thermal Cycler PERSONAL (Takara Bio). The annealing temperature was $58^{\circ} \mathrm{C}$ for Aurantiochytrium and $62^{\circ} \mathrm{C}$ for Parietichytrium and Ulkenia. The PCR products were electrophoresed on a $2 \%$ agarose gel and stained with ethidium bromide.

We performed qPCR of the above-mentioned DNA extracts from 7 genera. A mixture (total volume: $20 \mu \mathrm{l}$ ) containing $0.5 \mu \mathrm{l}$ of template DNA (dissolved as described above), $0.4 \mu \mathrm{l}$ of $10 \mathrm{pmol} \mathrm{\mu l}^{-1}$ genusspecific forward and reverse primers, and $10 \mu \mathrm{l}$ of Platinum ${ }^{\circledR}$ SYBR ${ }^{\circledR}$ Green qPCR SuperMix-UDG with ROX $^{\mathrm{TM}}$ (Invitrogen) was analyzed in an ABI PRISM 7000 (Applied Biosystems) using the following thermal protocol: 1 cycle at $50^{\circ} \mathrm{C}$ for $2 \mathrm{~min}, 1$ cycle at $95^{\circ} \mathrm{C}$ for $2 \mathrm{~min}$, and $40 \mathrm{cycles}$ at $95^{\circ} \mathrm{C}$ for $15 \mathrm{~s}$ and $60^{\circ} \mathrm{C}$ for $30 \mathrm{~s}$. Following qPCR, the melting profiles of the PCR product versus temperature (dissociation curves) were obtained for each sample to check for the occurrence of positive amplification of target DNA and absence of primer-dimers.

\section{Quantification of thraustochytrid cells using qPCR}

The cell numbers for each culture were counted under a light microscope, and culture aliquots equivalent to 5000, 10000,100000 , and 1000000 cells were each filter-trapped onto a $0.22 \mu \mathrm{m}$ pore size Sterivex filter (Millipore). The filter units were then stored at $-20^{\circ} \mathrm{C}$ for a period $>1 \mathrm{~d}$. The units were thawed before DNA extraction and the cells lysed as described by Somerville et al. (1989). The crude lysates were used for DNA preparation by PCI extraction, CIA extraction, and isopropanol precipitation as described above. The DNA pellets were finally dissolved with $100 \mu \mathrm{l}$ of sterile MilliQ water. Triplicate aliquots of $0.5 \mu \mathrm{l}$ (each equivalent to 25,50,500, or 5000 cells reaction ${ }^{-1}$ ) were retrieved and subjected to qPCR using each genus-specific primer set, with sterile MilliQ water as a non-template control or a negative control. In addition, to determine whether each primer set produces a signal from non-target genera, a 5000 cell-equivalent DNA derived from each of the other genera was also subjected to qPCR. These qPCR measurements were characterized by 2 interrelated parameters: (1) the cycle threshold $\left(C_{\mathrm{t}}\right)$ value, i.e. the number of cycles at which the reaction crossed the specified fluorescence threshold; and (2) the normalized reporter signal (Rn), which is calculated as the ratio of the fluorescence of the reporter dye (SYBR ${ }^{\circledR}$ Green I) divided by the fluorescence of the passive reference dye (ROX $\left.{ }^{\mathrm{TM}}\right)$. The larger the amount of starting target DNA, the earlier a significant increase in $\mathrm{Rn}$ is observed, leading to a decrease in the $C_{t}$ value. The change in $R n$, or delta $R n(\Delta R n)$, was plotted against the cycle number of the reaction.

\section{Application of qPCR in testing seawater samples}

Seawater samples were collected at 88 sites around the islands of Koshiki-jima, Satsuma-Iwojima, and Tanega-shima (southwestern Japan), in the Seto Inland Sea (western Japan) during cruises of the RV 'Toyoshio-maru', Hiroshima University, in April 2008, May 2010, April 2011, and March and April 2012, and off the Karakuwa Peninsula in Sanriku (eastern Japan) during a cruise of the RV 'Tansei-maru', Japan Agency for Marine-Earth Science and Technology (JAMSTEC), in August 2011. In this study, qPCR only successfully quantified the thraustochytrid cell numbers in 8 of the 212 seawater samples, viz. those collected at sites around SatsumaIwojima and off the Karakuwa Peninsula (Fig. 1). (A detailed list of all 212 samples is given in Table S1 in the Supplement at www.int-res.com/articles/suppl/ m486p001_supp.pdf). Samples were collected using a conductivity, temperature, and depth (CTD) profiling rosette equipped with Niskin bottle samplers at between 1 and 4 depths (surface to $210 \mathrm{~m}$ ), depending on the water depth at the site.

From the 93 seawater samples collected in 2008, a 21 water sample was filtered through a $0.22 \mu \mathrm{m}$ pore size Sterivex filter (Millipore) using a peristaltic pump. The DNA was then extracted from the Sterivex housing as described above. From the 119 samples collected in 2010 to 2012, a 20 l water sample was prefiltered with a $500 \mu \mathrm{m}$ mesh, then filtered through a $0.22 \mu \mathrm{m}$ pore size Steripak-GP20 filter (Millipore) using a peristaltic pump. The DNA was extracted from this Steripak filter using PCI and CIA, as described by Frias-Lopez et al. (2008). Each DNA pellet was finally dissolved with 100 to $500 \mu$ l of sterile MilliQ water. Prior to $\mathrm{qPCR}$, the initial screening for confirmation of the existence of thraustochytrids was performed by conventional PCR. Amplicons from the DNA extract with a minimum of 3 cells reaction ${ }^{-1}$ could be reliably detected on an agarose gel by ethidium bromide staining. Therefore, this initial screening was used to select the samples applicable for our qPCR system to quantitate thraustochytrid cells rang- 

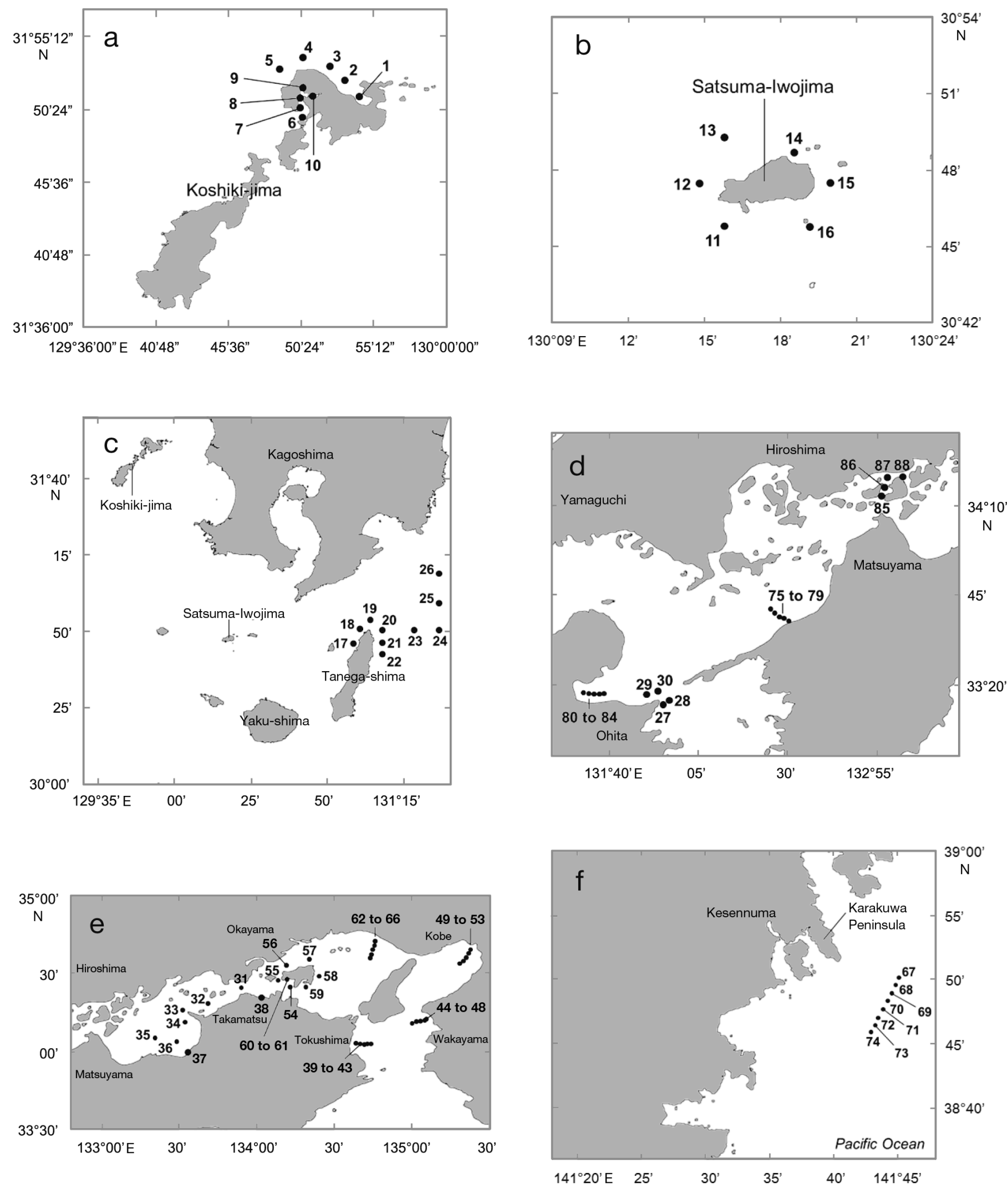

Fig. 1. Locations of sample collection in the area surrounding (a) Koshiki-jima, (b) Satsuma-Iwojima, and (c) Tanega-shima, $(d, e)$ in the Seto Inland Sea, and (f) off the Karakuwa Peninsula in Sanriku 
Table 2. Sequences and amplicon sizes of genus-specific PCR primer sets

\begin{tabular}{|c|c|c|c|}
\hline Genus & Name & Sequence & $\begin{array}{l}\text { Amplicon } \\
\text { size (bp) }\end{array}$ \\
\hline Aurantiochytrium & $\begin{array}{l}\text { Aur-F } \\
\text { Aur-R }\end{array}$ & $\begin{array}{l}\text { 5'-CTACGGTGACTATAACGGGTG-3' } \\
\text { 5'-GTGGAGTCCACAGTGGGTAA-3' }\end{array}$ & 120 \\
\hline Botryochytrium & $\begin{array}{l}\text { Bot-F } \\
\text { Bot-R }\end{array}$ & $\begin{array}{l}\text { 5'-ATGTGAGTGCGATAGCTTTCG-3' } \\
\text { 5'-CGATTGCCTTCACACAAAAATG-3' }\end{array}$ & 92 \\
\hline Oblongichytrium & $\begin{array}{l}\text { Obl-F } \\
\text { Obl-R }\end{array}$ & $\begin{array}{l}\text { 5'-GAGCCTTCGGGTTCGTGT-3' } \\
\text { 5'-AACGATATGGATCCCATGCC-3' }\end{array}$ & 93 \\
\hline Parietichytrium & $\begin{array}{l}\text { Par-F } \\
\text { Par-R }\end{array}$ & $\begin{array}{l}\text { 5'-TTCGTAAGAGAACCAAATGTGG-3' } \\
\text { 5'-GCCATGCAAACCAACAAAAT-3' }\end{array}$ & 164 \\
\hline Sicyoidochytrium & $\begin{array}{l}\text { Sic-F } \\
\text { Sic-R }\end{array}$ & $\begin{array}{l}\text { 5'-ACGAGGAAAAAGTCCTTATCCG-3' } \\
\text { 5'-TACGCTACATCAAACTTTCATCC-3' }\end{array}$ & 235 \\
\hline Schizochytrium & $\begin{array}{l}\text { Sch-F } \\
\text { Sch-R }\end{array}$ & $\begin{array}{l}\text { 5'-AATTCCCATGATTGTGCGTTGTGT-3' } \\
\text { 5'-CCCGAGGGCTATGCGATTCGCTC-3' }\end{array}$ & ; 172 \\
\hline Ulkenia & $\begin{array}{l}\text { Ulk-F } \\
\text { Ulk-R }\end{array}$ & $\begin{array}{l}\text { 5'-GGGCTAAGCCTACTCTTTCTG-3' } \\
\text { 5'-CTGGTCCGTCCTACCAATACTT-3' }\end{array}$ & 168 \\
\hline
\end{tabular}

in the number of PCR cycles from 40 to 35 to minimize potential interference by non-specific amplification. DNA extracts from the culture strain of the target genus, each corresponding to 25 , 50,500 , or 5000 cells reaction ${ }^{-1}$, were loaded for every run to serve as quantification standards (all performed in triplicate). The abundance of each genus was determined based on these culturebased standardizations.

For the 8 samples for which thraustochytrids were quantified by $\mathrm{qPCR}$, we tested for interference due to other co-extracted compounds (e.g., organic acids or polysaccharides) or from filter-

ing from 25 to 5000 cells reaction ${ }^{-1}$. This step was included to reduce the effort and cost associated with qPCR. A mixture (total volume: $20 \mu \mathrm{l}$ ) containing $0.5 \mu \mathrm{l}$ of template DNA, pooled primers comprising $0.7 \mu \mathrm{l}$ of $10 \mathrm{pmol} \mathrm{ll}^{-1}$ of each forward and reverse primer, and the recommended volume of 5 units $\mu^{-1}$ Ex Taq DNA polymerase, 10× Ex Taq buffer, $25 \mathrm{mM}$ $\mathrm{MgCl}_{2}$, and dNTP mixture included in the Takara Ex Taq kit (Takara Bio) was used in the conventional PCR. The thermal-cycling protocol consisted of 1 cycle at $95^{\circ} \mathrm{C}$ for $2 \mathrm{~min}, 35$ cycles at $94^{\circ} \mathrm{C}$ for $30 \mathrm{~s}$, $60^{\circ} \mathrm{C}$ for $45 \mathrm{~s}$, and $72^{\circ} \mathrm{C}$ for $40 \mathrm{~s}$, followed by 1 cycle at $72^{\circ} \mathrm{C}$ for $10 \mathrm{~min}$. This cycle number (35 cycles) was chosen based on the $C_{\mathrm{t}}$ values and $\Delta \mathrm{Rn}$ values obtained during the qPCR amplification of standard DNA. In the preliminary experiments with pooled primers, some losses in PCR performance were observed. We therefore reduced the primer concentration and optimized the PCR reaction conditions using control DNAs. The PCR products were electrophoresed on a $2 \%$ agarose gel and stained with ethidium bromide. For samples that tested positive using the mix of primers, we performed PCR using each forward and reverse primer to determine the presence or absence of each genus.

For samples that tested positive during conventional PCR-based screening, we conducted qPCR using the primer sets described above. A mixture (total volume $20 \mu \mathrm{l}$ ) containing $0.5 \mu \mathrm{l}$ of template DNA, $0.4 \mu \mathrm{l}$ of $10 \mathrm{pmol} \mathrm{ll}^{-1}$ genus-specific forward and reverse primers, and $10 \mu \mathrm{l}$ of Platinum ${ }^{\circledR} \mathrm{SYBR}^{\circledR}$ Green qPCR SuperMix-UDG with ROX ${ }^{\mathrm{TM}}$ (Invitrogen) was analyzed in an ABI PRISM 7000 (Applied Biosystems), as described above, but with a decrease trapped particles in the qPCR by adding 50 or 500 cell equivalents of DNA from the culture strains to every sample as internal standards. The additional increase in the qPCR signal corresponding to the additional DNAs was recorded. When interference was suspected, the samples were diluted sufficiently to diminish interference. In addition, the 6 samples in which thraustochytrid cells were found and strong amplification was observed by conventional PCR but not qPCR were checked for amplification inhibition in the same manner. To compare the results of qPCR with traditional acriflavine counts, 125 of the 212 samples were counted with acriflavine using epifluorescence microscopy following the method described by Raghukumar \& Schaumann (1993). Briefly, particles in a water sample of 10- to $100 \mathrm{ml}$ were collected on an isopore membrane filter (Millipore; pore size $0.2 \mu \mathrm{m}$, diameter $25 \mathrm{~mm}$ ). The particles on the filter were stained with $4 \mathrm{ml}$ of $0.2 \mu \mathrm{m}$ filtered $0.05 \%$ acriflavine in $0.1 \mathrm{M}$ citrate buffer (pH 3.0) for $4 \mathrm{~min}$ and then rinsed with $75 \%$ isopropanol for $1 \mathrm{~min}$. Thraustochytrid cells were counted in 100 microscopic fields, and each count was duplicated.

\section{RESULTS AND DISCUSSION}

\section{PCR specificity}

The sequence and amplicon size of the qPCR primer sets designed to amplify each 18S rRNA gene of 7 thraustochytrid genera are given in Table 2 . Some primer sets had mismatches with target thraustochytrid sequences ranging from 1 to 5 bases. 
Aurantiochytrium sp. SEK 209 (AB290574) had a 1base difference with our Aurantiochytrium-specific reverse primer; Oblongichytrium sp. SEK 347 (AB290575) had a 1-base difference with our forward primer; and Ulkenia profunda (L34054) had a 5-base difference ( 2 in the forward primer and 3 in the reverse) with our primers. The desired amplifications against each genus were simulated in the PrimerBLAST database search. Mismatched regions were also found in the search results. For example, Aurantiochytrium sp. B013 (JF266573) had a 4-base difference ( 2 in the forward primer and 2 in the reverse) with our primers; and Parietichytrium sp. BAFCcult 3109 (HQ228977) had a 2-base difference with our forward primer.

In addition, Primer-BLAST results suggested that the reverse primer for detection of Parietichytrium attaches to 2 regions in each genome of the coelacanth Latimeria menadoensis (AC215904), the nematode Caenorhabditis elegans (Z68116), and the bacterium Acinetobacter sp. ADP1 (CR543861) and produces unexpected PCR products. In contrast, the forward primer did not match with these 3 sequences. The L. menadoensis had a 4-base difference (1 in the one region and 3 in the other region; predicted product size: $231 \mathrm{bp}$ ), the $C$. elegans had a 6-base difference (3 in the one region and 3 in the other region; $1148 \mathrm{bp}$ ), and the Acinetobacter sp. had a 7-base difference $(2$ in the one region and 5 in the other region; $3148 \mathrm{bp}$ ) with the reverse primer. These product sizes were easily distinguishable from the predicted product size of $164 \mathrm{bp}$ for Parietichytrium. Moreover, because the $C$. elegans sequence has a mismatch at the 3 '-end of the reverse primer, we predict that PCR amplification will not proceed. While our primers were not perfect in all instances, they matched the designated genera in the database. Furthermore, we used conventional PCR to confirm positive PCR amplification of the target thraustochytrid genus and negative amplification of other non-target genera (Fig. 2).

\section{qPCR quantification of 7 thraustochytrid genera}

The relationship between $C_{\mathrm{t}}$ values and a logarithmic plot of cell numbers of each thraustochytrid genus $\left(25,50,500,5000\right.$ cells reaction $\left.^{-1}\right)$ yielded a strong linear correlation (Fig. 3). Linear regression fits between cell numbers of standard genus $(X)$ and the corresponding $C_{\mathrm{t}}$ values $(Y)$ for these runs are described in Fig. 3. Despite several attempts, we were unable to quantify cell numbers in filtered samples with $<25$ cells reaction ${ }^{-1}$ using the current qPCR

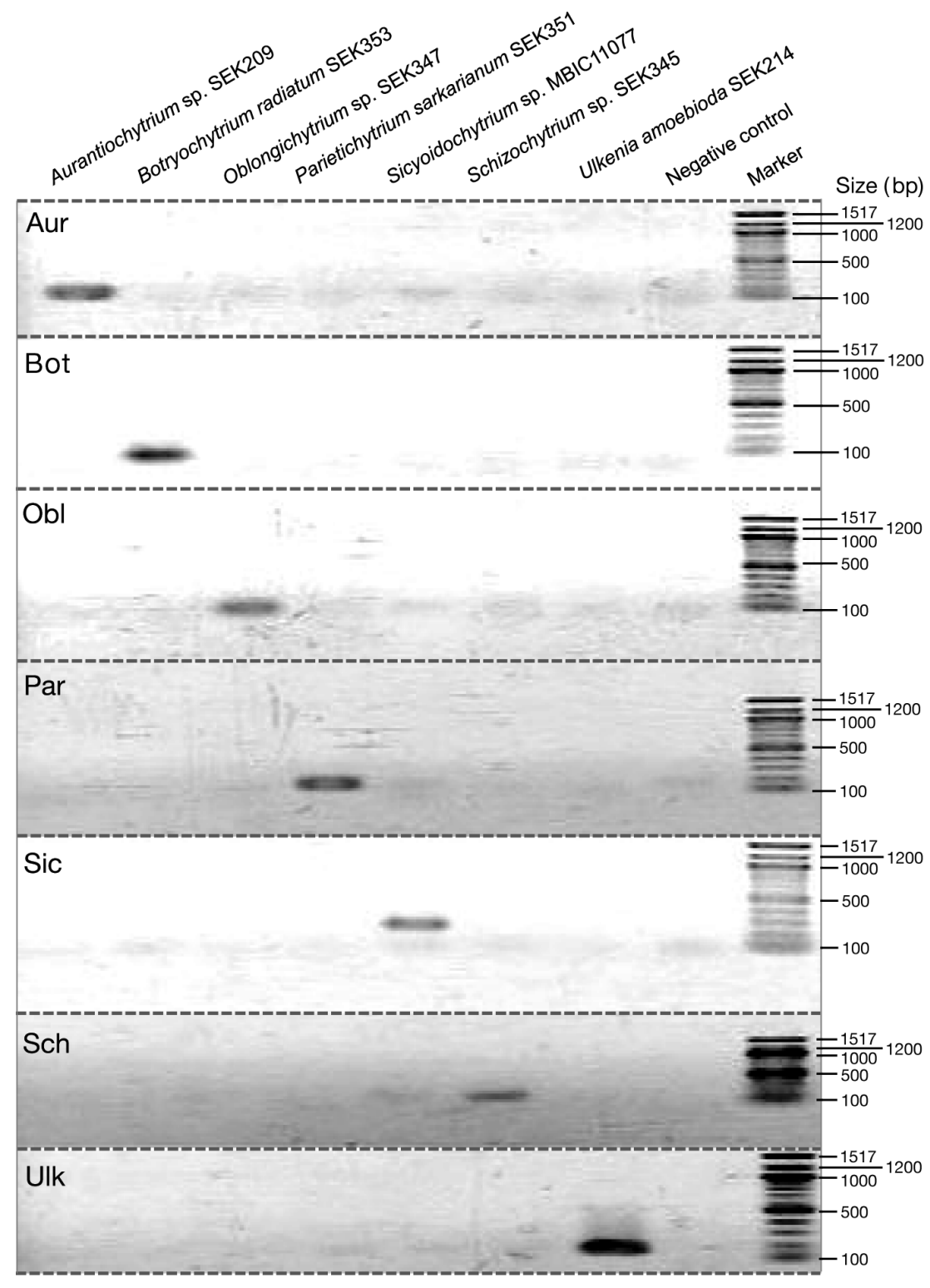

Fig. 2. Agarose gel electrophoresis of PCR-amplified products with genus-specific primer sets against target and non-target DNA solutions. Aur, Bot, Obl, Par, Sic, Sch, and Ulk represent Aurantiochytrium-, Botryochytrium-, Oblongichytrium-, Parietichytrium-, Sicyoidochytrium-, Schizochytrium-, and Ulkenia-specific primer sets, respectively, that were used for each amplification 
assay (data not shown). In addition, in the 4 assays for Botryochytrium, Schizochytrium, Sicyoidochytrium, and Ulkenia, the amplification efficiencies were high, ranging from 90.8 to $107.1 \%$. The efficiencies of the other 3 primer sets ranged from approximately 70.4 to $81.5 \%$; this suggests that there is room for improvement. However, all assays designed in this study had comparable levels of detection limits as described below.

The $\Delta$ Rn curves for the 7 genera and primer sets are summarized in Fig. 4. The graphs for the Aurantiochytrium, Botryochytrium, Oblongichytrium, Schizochytrium, and Sicyoidochytrium-specific primers clearly illustrate a significant increase in $\Delta \mathrm{Rn}$ of each target genus in comparison with the 5000 cell-equivalent DNAs derived from 1 of the other 6 non-target genera. Our data also suggest that for these 5 genera, the increase in the non-specific $\Delta \mathrm{Rn}$ may have occurred in later PCR cycles (typically beyond 33 to 35 cycles; Fig. 4). Based on the thermal dissociation curve analysis of the qPCR amplicons, such an increase in $\Delta \mathrm{Rn}$ would likely result from the amplification of non-target DNA. In addition, for the Sicyoidochytrium-specific primer set, a weak peak from the formation of primer-dimers occurred, and the signal was recognized after 35 cycles as described in the
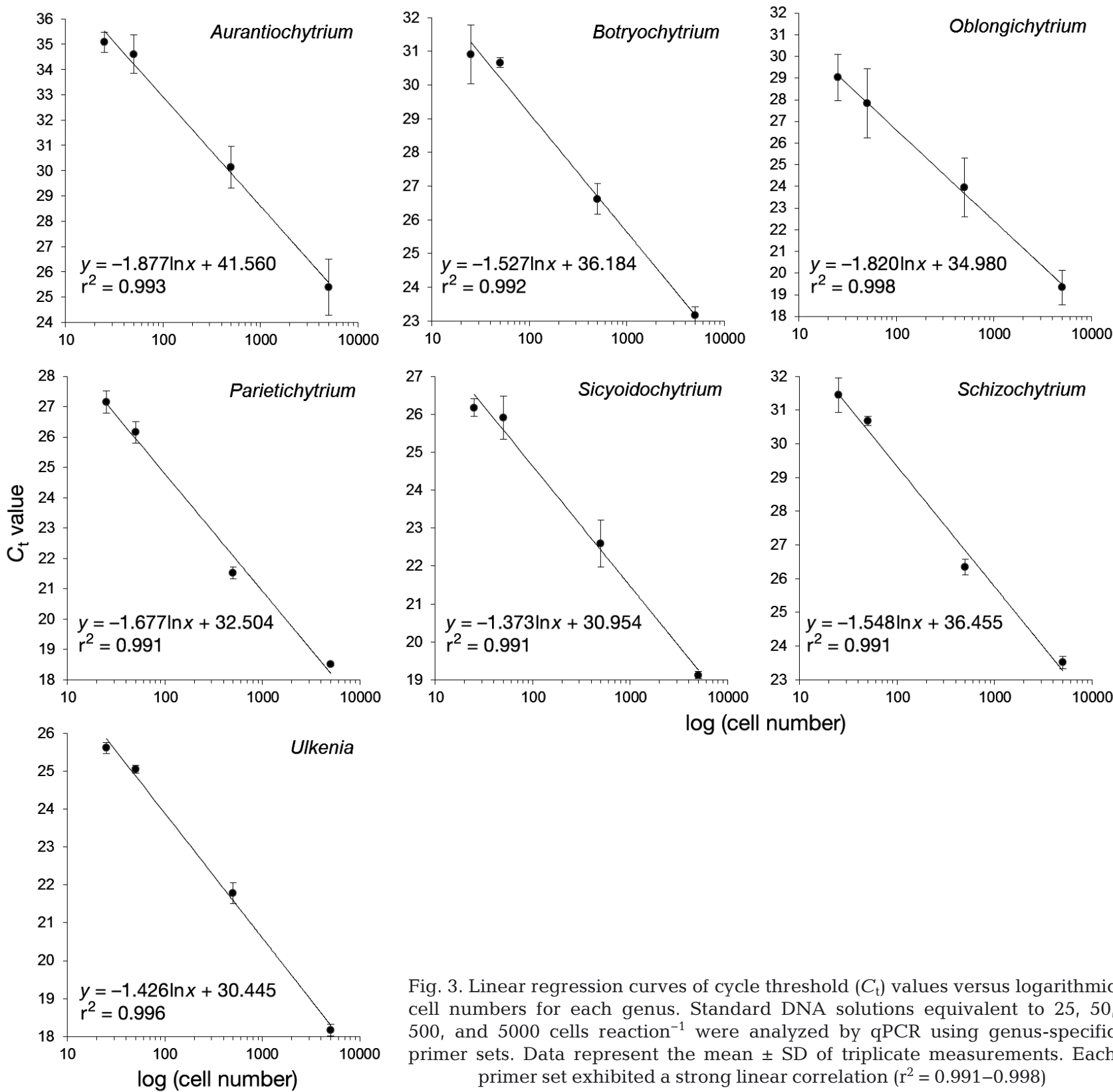

Fig. 3. Linear regression curves of cycle threshold $\left(C_{\mathrm{t}}\right)$ values versus logarithmic cell numbers for each genus. Standard DNA solutions equivalent to 25, 50, 500, and 5000 cells reaction $^{-1}$ were analyzed by qPCR using genus-specific primer sets. Data represent the mean \pm SD of triplicate measurements. Each primer set exhibited a strong linear correlation $\left(r^{2}=0.991-0.998\right)$ 
non-template control (NTC) reaction result (Fig. 4). However, in our qPCR system, the $\Delta \mathrm{Rn}$ for the 25 cells reaction $^{-1}$ as the detection limit was observed in $C_{\mathrm{t}}$ values ranging from 26 to 32 cycles (Fig. 3). To minimize the effect of such signals, the number of PCR cycles was reduced from 40 to 35 during analysis of the field samples. Thus, the signals derived from nonspecific amplification or primer-dimers have no real influence on our results. In the case of Aurantiochytrium, the $C_{\mathrm{t}}$ value $(35.1 \pm 0.4 \mathrm{SD} ; \mathrm{n}=3)$ for the 25 cell equivalent could not be discriminated from the signal of the non-target DNA amplified. Conversely, for the Parietichytrium and Ulkenia-specific primers, the increase in $\Delta \mathrm{Rn}$ derived from the amplification of non-target genera DNA appeared to occur relatively quickly, after 27 cycles. This cycle number is similar to the $C_{\mathrm{t}}$ values for the Parietichytrium 25 cell equivalent $(27.1 \pm 0.3$, mean $\pm \mathrm{SD} ; \mathrm{n}=3)$ and the Ulkenia 25 cell equivalent $(25.6 \pm 0.1 ; \mathrm{n}=3$ ) samples (Fig. 3 ). However, in the case of non-target genera not being detected in the sample by conventional PCR-based screening, the non-specific $\Delta \mathrm{Rn}$ is considered to have no real effect on the qPCR results. We emphasize that prior to the qPCR assay, we performed conventional PCR to determine the presence or absence of each thraustochytrid genus. This was necessary to confirm background genera that could affect the quantification in $\mathrm{qPCR}$.
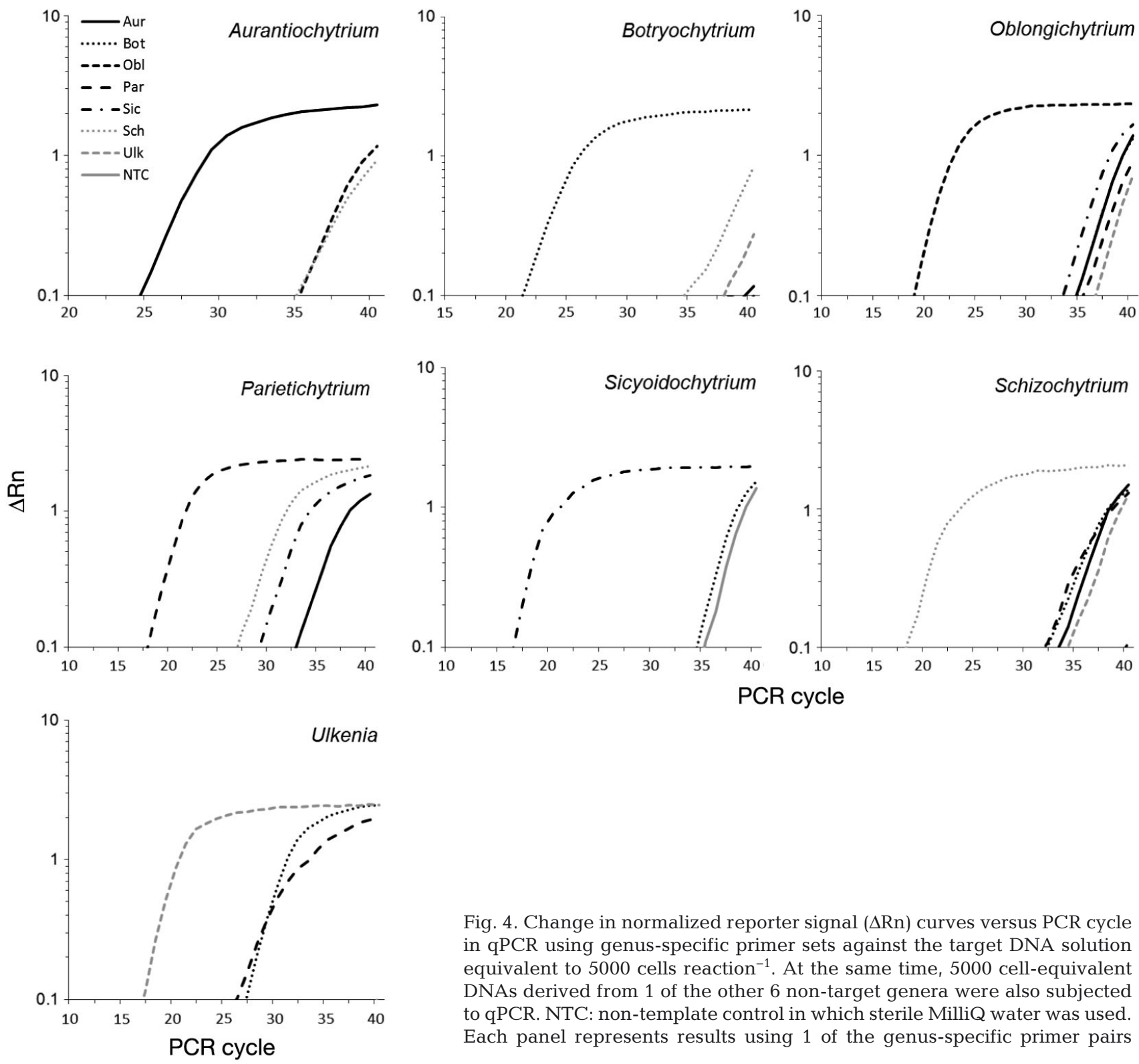

Fig. 4. Change in normalized reporter signal $(\Delta \mathrm{Rn})$ curves versus PCR cycle in qPCR using genus-specific primer sets against the target DNA solution equivalent to 5000 cells reaction ${ }^{-1}$. At the same time, 5000 cell-equivalent DNAs derived from 1 of the other 6 non-target genera were also subjected to qPCR. NTC: non-template control in which sterile MilliQ water was used. Each panel represents results using 1 of the genus-specific primer pairs 
Table 3. Thraustochytrid cell numbers estimated from traditional acriflavine counts and qPCR. -: no data; ND: not detected

\begin{tabular}{|c|c|c|c|c|c|c|}
\hline Sample no. & $\begin{array}{l}\text { Site } \\
\text { no. }\end{array}$ & Area description & $\begin{array}{l}\text { Depth } \\
(\mathrm{m})\end{array}$ & $\begin{array}{l}\text { Direct count estimates } \\
\qquad\left(\times 10^{3} \text { cell }^{-1}\right)\end{array}$ & $\begin{array}{l}\text { qPCR estimates } \\
\text { Aurantiochytrium }\end{array}$ & $\begin{array}{l}\left(\times 10^{3} \text { cell } \mathrm{l}^{-1}\right) \\
\text { Oblongichytrium }\end{array}$ \\
\hline \multicolumn{7}{|l|}{ April 2008} \\
\hline I1-1 & 11 & $\begin{array}{l}\text { Around Satsuma-Iwojima } \\
\text { Island, southwestern Japan }\end{array}$ & 1 & $16.0 \pm 6.4$ & $11.2 \pm 1.5$ & $15.3 \pm 1.8$ \\
\hline $\mathrm{I} 1-2$ & 11 & & 70 & - & ND & $31.4 \pm 3.6$ \\
\hline $\mathrm{I} 2-1$ & 12 & & 1 & $3.4 \pm 3.3$ & ND & $15.9 \pm 1.1$ \\
\hline $\mathrm{I} 4$ & 14 & & Surface water & $6.6 \pm 9.1$ & $13.1 \pm 1.6$ & $10.2 \pm 2.3$ \\
\hline I5-1 & 15 & & 1 & $3.1 \pm 3.6$ & ND & $12.8 \pm 1.2$ \\
\hline I6-1 & 16 & & 1 & $8.0 \pm 7.9$ & ND & $14.6 \pm 2.4$ \\
\hline \multicolumn{7}{|l|}{ August 2011} \\
\hline St16-3 & 69 & $\begin{array}{l}\text { Off Karakuwa Peninsula } \\
\text { in Sanriku, eastern Japan }\end{array}$ & 1 & $9.6 \pm 1.1$ & ND & $15.9 \pm 1.8$ \\
\hline St16-6 & 72 & & 1 & $5.3 \pm 3.2$ & ND & $17.9 \pm 1.9$ \\
\hline
\end{tabular}

Based on our results, the determination limit was 25 cells reaction ${ }^{-1}$ for 6 genera (Botryochytrium, Oblongichytrium, Parietichytrium, Schizochytrium, Sicyoidochytrium, and Ulkenia), and 50 cells reaction ${ }^{-1}$ for 1 genus (Aurantiochytrium). Given the appropriate dilution covering the standard range, the quantitative results obtained by our qPCR analyses were acceptable, as we obtained a linear relationship between cell numbers and $C_{\mathrm{t}}$ values for all genera (Fig. 3).

\section{Using qPCR to enumerate thraustochytrid cells in the marine environment}

Using our qPCR assay, we enumerated planktonic thraustochytrid cells in field samples. We successfully detected the presence of Aurantiochytrium (in the range of $1.12 \times 10^{4}$ to $1.31 \times 10^{4}$ cells $1^{-1}$ ) and Oblongichytrium (in the range of $1.02 \times 10^{4}$ to $3.14 \times$ $10^{4}$ cells $\mathrm{l}^{-1}$ ) in 8 surface-seawater samples from around Satsuma-Iwojima and off the Karakuwa Peninsula in Sanriku (Table 3). However, the other 5 genera (Botryochytrium, Parietichytrium, Schizochytrium, Sicyoidochytrium, and Ulkenia) were not quantifiable in any of the samples. If the number of PCR cycles was increased, our qPCR assay may have detected and quantified a smaller number of thraustochytrid cells (as illustrated in Fig. 3). However, in this case the disadvantage resulting from an increase in the non-specific $\triangle \mathrm{Rn}$ in later PCR cycles, as described in Fig. 4, would be relatively conspicuous.

Of the 8 qPCR-positive samples, we tested 7 using the traditional acriflavine count, which yielded lower estimates for cell abundance in all cases (Table 3), with a weak positive correlation $\left(\mathrm{r}^{2}=0.495\right.$; Fig. 5; raw count data are given in Table S1 in the Supple- ment). We speculate that the acriflavine count excludes thraustochytrid zoospores because of the fact that zoospores of most thraustochytrid species lack a cell wall (Moss 1986). In addition, very small cells $(<5 \mu \mathrm{m})$ are not easily distinguished because the cell wall-associated red fluorescence is weaker than the

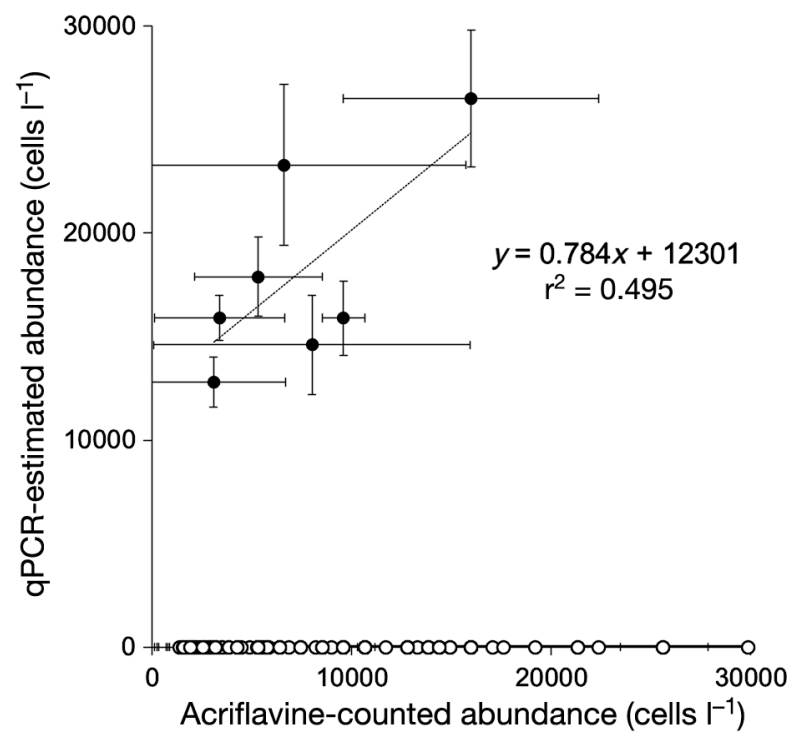

Fig. 5. Correlation between traditional microscopic and qPCR-derived estimates for thraustochytrid abundance. For the samples (Sites 11 and 14) in which more than 1 genus was detected by qPCR, the sum of the value for each genus was defined as a qPCR-derived estimate. Only 7 of the 212 water samples were quantified by both direct count and qPCR $(\bullet)$. There was a weak positive correlation between the 2 methods $\left(\mathrm{r}^{2}=0.495\right)$. In an additional 104 samples, thraustochytrid cells were quantified by direct count (O); 6 of these samples exhibited strong bands when amplified by conventional PCR screening but could not be quantified by qPCR. The 7 samples containing more than $3 \times 10^{4}$ cells $l^{-1}$ are not included 
nucleus-associated green fluorescence. Thus, these cells are often not counted, leading to underestimation. Taken together, our observations suggest that qPCR provides a more accurate estimate of the abundance of these zoospores and very small cells.

Thraustochytrid cells were found in 104 additional samples by direct count. The abundance of thraustochytrids ranged from $1.37 \pm 1.22 \times 10^{3}{\text { cells } l^{-1}}^{-1}$ (Site 20, around Tanega-shima, southwestern Japan)

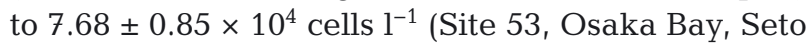
Inland Sea, western Japan; Table S1). Prior studies reported an average thraustochytrid abundance of $10^{3}$ to $10^{4}$ cells (Naganuma et al. 1998, Kimura et al. 1999, 2001) in the coastal Seto Inland Sea and adjacent open waters. Our direct count estimates of abundance were consistent with prior studies. However, for these samples, thraustochytrids could not be quantified by qPCR, although 6 did produce strong bands when amplified by conventional PCR (Table S1). We suspect that contamination with non-target DNAs derived from smaller microorganisms and/or other co-extracted compounds, such as organic acids or polysaccharides, inhibits the amplification reaction. This is consistent with the decrease in signals we observed for the 500 cell internal standard used in the qPCR runs with the 6 samples above (data not shown). Given this, we recommend further evaluation of methods for filtration to remove picoeukaryotes and bacteria. Moreover, recent culture-independent studies revealed that thraustochytrid 18S rRNA gene sequences in the environment were more phylogenetically diverse than expected (Collado-Mercado et al. 2010). There is the possibility that the presence of these novel thraustochytrid groups could not be detected, which may have affected our results.

\section{Properties of the qPCR developed in the present study}

We have developed and applied a SYBR ${ }^{\circledR}$ Green qPCR method for the identification and quantification of 7 thraustochytrid genera. Our initial objective was to estimate genus-specific abundances of the family Thraustochytriaceae, all of which were based on the qPCR results. Therefore, our qPCR system has targeted the specific regions of 18S rRNA gene from representative strains for each genus. Expressing this parameter as the copy number of an rRNA gene would be more accurate, but less insightful for ecological purposes. Thus, we calculated cell numbers using the formula obtained from $C_{\mathrm{t}}$ values versus cell numbers of cultured strains. The qPCR-based cell number was determined based on each independ- ent genus standard. Therefore, our culture-based standardizations should give independent levels of detection and should not be affected by differences in the rRNA gene copy numbers among the genera. In contrast, since the environmental samples may contain multiple and/or unknown species of each genus, there was the potential that the copy number variations within each genus affect the qPCR estimates. Zhu et al. (2005) studied the copy number variations of 18 algal strains belonging to different phylogenetic groups and suggested that qPCR could be used to monitor specific narrow groups since the range of rRNA gene copy numbers was quite restricted. Thus, the difference in copy number within genus does not seem to present a significant obstacle to the determination of cell number based on the culture-based standardizations. Nevertheless, accurate quantification that takes the copy number variations into consideration is desirable, as this has not been conclusively determined so far. Although the trials for natural samples are still preliminary, our molecular approach can provide the genus-specific value of abundance in the environment. It could also help advance our understanding of thraustochytrid diversity.

Acknowledgements. We thank the crews of the RV 'Toyoshio-maru', Hiroshima University, and the RV 'Tanseimaru', Japan Agency for Marine Earth Science and Technology (JAMSTEC), and the cruise participants for their onboard assistance. We thank K. Koike, Hiroshima University, for allowing sample collection during the RV 'Toyoshiomaru' Cruise No. 2010-02 and K. Hamasaki, University of Tokyo, for allowing sample collection during the RV 'Tanseimaru' Cruise KT-11-17. We especially thank T. Nagata, University of Tokyo, N. Nagano, Kyushu University, and H. Yamashita, Seikai National Fisheries Research Institute, and $\mathrm{K}$. Inoue, University of Tokyo, for their on-board assistance and helpful discussion. R.N. was supported by JSPS Research Fellowships for Young Scientists (10J07702 and 11J30005). We also thank 3 anonymous reviewers for their careful reading and constructive remarks.

\section{LITERATURE CITED}

Altschul SF, Madden TL, Schaffer AA, Zhang J, Zhang Z, Miller W, Lipman DJ (1997) Gapped BLAST and PSIBLAST: a new generation of protein database search programs. Nucleic Acids Res 25:3389-3402

Bergmann N, Fricke B, Schmidt MC, Tams V and others (2011) A quantitative real-time polymerase chain reaction assay for the seagrass pathogen Labyrinthula zosterae. Mol Ecol Resour 11:1076-1081

> Bowers HA, Tengs T, Glasgow HB Jr, Burkholder JM, Rublee PA, Oldach DW (2000) Development of real-time PCR assays for rapid detection of Pfiesteria piscicida and related dinoflagellates. Appl Environ Microbiol 66: 4641-4648 
Bremer GB (1995) Lower marine fungi (Labyrinthulomycetes) and the decay of mangrove leaf litter. Hydrobiologia 295:89-95

Cavalier-Smith T, Chao EE (2006) Phylogeny and megasystematics of phagotrophic heterokonts (Kingdom Chromista). J Mol Evol 62:388-420

Cavalier-Smith T, Allsopp M, Chao EE (1994) Thraustochytrids are chromists, not fungi: signature sequences of Heterokonta. Philos Trans R Soc Lond B Biol Sci 346:387-397

> Collado-Mercado E, Radway JC, Collier JL (2010) Novel uncultivated labyrinthulomycetes revealed by $18 \mathrm{~S}$ rDNA sequences from seawater and sediment samples. Aquat Microb Ecol 58:215-228

> Damare V, Raghukumar S (2010) Association of the stramenopilan protists, the aplanochytrids, with zooplankton of the equatorial Indian Ocean. Mar Ecol Prog Ser 399: $53-68$

> Frias-Lopez J, Shi Y, Tyson GW, Coleman ML, Schuster SC, Chisholm SW, Delong EF (2008) Microbial community gene expression in ocean surface waters. Proc Natl Acad Sci USA 105:3805-3810

- Honda D, Yokochi T, Nakahara T, Raghukumar S, Nakagiri A, Schaumann K, Higashihara T (1999) Molecular phylogeny of thraustochytrids based on the sequencing of $18 \mathrm{~S}$ ribosomal RNA gene. J Eukaryot Microbiol 46:637-647

Kimura H, Naganuma T (2001) Thraustochytrids: a neglected agent of the marine microbial food chain. Aquat Ecosyst Health Manag 4:13-18

Kimura H, Fukuba T, Naganuma T (1999) Biomass of thraustochytrid protoctists in coastal water. Mar Ecol Prog Ser 189:27-33

Kimura H, Sato M, Sugiyama C, Naganuma T (2001) Coupling of thraustochytrids and POM, and of bacterio- and phytoplankton in a semi-enclosed coastal area: implication for different substrate preference by the planktonic decomposers. Aquat Microb Ecol 25:293-300

Larkin MA, Blackshields G, Brown NP, Chenna R and others (2007) Clustal W and Clustal X version 2.0. Bioinformatics 23:2947-2948

> Liu Q, Allam B, Collier JL (2009) Quantitative real-time PCR assay for QPX (Thraustochytriidae), a parasite of the hard clam (Mercenaria mercenaria). Appl Environ Microbiol 75:4913-4918

Lyons MM, Smolowitz R, Dungan CF, Roberts SB (2006) Development of a real time quantitative PCR assay for the hard clam pathogen Quahog Parasite Unknown (QPX). Dis Aquat Org 72:45-52

$>$ Moorthi SD, Countway PD, Stauffer BA, Caron DA (2006) Use of quantitative real-time PCR to investigate the dynamics of the red tide dinoflagellate Lingulodinium polyedrum. Microb Ecol 52:136-150

Moss ST (1986) Biology and phylogeny of the Labyrinthulales and Thraustochytriales. In: Moss ST (ed) The biology of marine fungi. Cambridge University Press, Cambridge, p 105-129

Nagano N, Matsui S, Kuramura T, Taoka Y, Honda D, Hayashi M (2011) The distribution of extracellular cellulase activity in marine Eukaryotes, thraustochytrids. Mar Biotechnol (NY) 13:133-136

Editorial responsibility: Hans Heinrich Janssen, Oldendorf/Luhe, Germany
Naganuma T, Takasugi H, Kimura H (1998) Abundance of thraustochytrids in coastal plankton. Mar Ecol Prog Ser 162:105-110

Naganuma T, Kimura H, Karimoto R, Pimenov NV (2006) Abundance of planktonic thraustochytrids and bacteria and the concentration of particulate ATP in the Greenland and Norwegian seas. Polar Biosci 20:37-45

Raghukumar S (2008) Thraustochytrid marine protists: production of PUFAs and other emerging technologies. Mar Biotechnol (NY) 10:631-640

Raghukumar S, Damare VS (2011) Increasing evidence for the important role of Labyrinthulomycetes in marine ecosystems. Bot Mar 54:3-11

Raghukumar S, Schaumann K (1993) An epifluorescence microscopy method for direct detection and enumeration of the fungi-like marine protists, the thraustochytrids. Limnol Oceanogr 38:182-187

Raghukumar S, Ramaiah N, Raghukumar C (2001) Dynamics of thraustochytrid protists in the water column of the Arabian Sea. Aquat Microb Ecol 24:175-186

Sathe-Pathak V, Raghukumar S, Raghukumar C, Sharma S (1993) Thraustochytrid and fungal component of marine detritus. I. Field studies on decomposition of the brown alga Sargassum cinereum J. Ag. Indian J Mar Sci 22: 159-167

Somerville CC, Knight IT, Straube WL, Colwell RR (1989) Simple, rapid method for direct isolation of nucleic acids from aquatic environments. Appl Environ Microbiol 55: $548-554$

Takao Y, Tomaru Y, Nagasaki K, Sasakura Y, Yokoyama R, Honda D (2007) Fluorescence in situ hybridization using 18S rRNA-targeted probe for specific detection of thraustochytrids (Labyrinthulomycetes). Plankton Benthos Res 2:91-97

> Yamashita H, Suzuki G, Hayashibara T, Koike K (2011) Do corals select zooxanthellae by alternative discharge? Mar Biol 158:87-100

> Ye J, Coulouris G, Zaretskaya I, Cutcutache I, Rozen S, Madden T (2012) Primer-BLAST: a tool to design targetspecific primers for polymerase chain reaction. BMC Bioinformatics 13:134

Yokoyama R, Honda D (2007) Taxonomic rearrangement of the genus Schizochytrium sensu lato based on morphology, chemotaxonomical characteristics, and 18S rRNA gene phylogeny (Thraustochytriaceae, Labyrinthulomycetes): emendation for Schizochytrium and erection of Aurantiochytrium and Oblongichytrium gen. nov. Mycoscience 48:199-211

Yokoyama R, Salleh B, Honda D (2007) Taxonomic rearrangement of the genus Ulkenia sensu lato phylogeny based on morphology, chemotaxonomical characteristics, and 18S rRNA gene (Thraustochytriaceae, Labyrinthulomycetes): emendation for Ulkenia and erection of Botryochytrium, Parietichytrium and Sicyoidochytrium gen. nov. Mycoscience 48:329-341

Zhu F, Massana R, Not F, Marie D, Vaulot D (2005) Mapping of picoeucaryotes in marine ecosystems with quantitative PCR of the 18S rRNA gene. FEMS Microbiol Ecol 52: 79-92

Submitted: September 12, 2012; Accepted: May 16, 2013 Proofs received from author(s): June 22, 2013 